\title{
Real-time PCR methods for quantitative monitoring of streptomycin and tetracycline resistance genes in agricultural ecosystems
}

\author{
F. Walsh, A. Ingenfeld, M. Zampicolli, M. Hilber-Bodmer, J.E. Frey, B. Duffy * \\ Agroscope Changins-Wädenswil ACW, Plant Protection Division, CH-8820 Wädenswil, Switzerland
}

\section{A R T I C L E I N F O}

Article history:

Received 23 December 2010

Received in revised form 15 April 2011

Accepted 17 April 2011

Available online 23 April 2011

\section{Keywords:}

Antibiotic resistance

Streptomycin

Tetracycline

Agriculture

qPCR

TaqMan ${ }^{\circledR}$

\begin{abstract}
A B S T R A C T
Antibiotic application in plant agriculture is primarily used to control fire blight caused by Erwinia amylovora in pome fruit orchards. In order to facilitate environmental impact assessment for antibiotic applications, we developed and validated culture-independent quantitative real-time PCR multiplex assays for streptomycin ( strA, strB, aadA and insertion sequence IS1133) and tetracycline (tetB, tetM and tetW) resistance elements in plant and soil samples. The qPCR were reproducible and consistent whether the DNA was extracted directly from bacteria, plant and soil samples inoculated with bacteria or soil samples prior to and after manure slurry treatment. The genes most frequently identified in soils pre- and post-slurry treatment were $\operatorname{str} B$, aad $A$, tet $B$ and tetM. All genes tested were detected in soils pre-slurry treatment, and a decrease in relative concentrations of tetB and the streptomycin resistance genes was observed in samples taken post-slurry treatment. These multiplex qPCR assays offer a cost-effective, reliable method for simultaneous quantification of antibiotic resistance genes in complex, environmental sample matrices.
\end{abstract}

(c) 2011 Elsevier B.V. All rights reserved.

\section{Introduction}

Antibiotic resistance studies have primarily focused on human and animal pathogen systems and been limited to culturable bacteria. The use of antibiotics in agriculture, for example as growth promoters in food-producing animals and in veterinary medicine has been proposed as a factor contributing to increased resistance in human pathogens (Goldman, 2004; Gould, 1999; Rezzonico et al., 2009; van den Bogaard and Stobberingh, 2000; Wegener, 2003; Witte, 1998). The extent to which agricultural environments contribute as potential reservoirs of antibiotic resistance genes is poorly understood. Approaches that evaluate culturable bacteria for presence of resistance phenotypes and qualitatively determine carriage of specific resistance genes by PCR are limited and in general deal with establishing the qualitative shifts of resistance determinants in response to selection pressures caused by agricultural applications.

Opinions differ on the influence of sub-inhibitory antibiotic concentrations in agriculture on selection and spread of antibiotic resistance in the environment (Commission on Antimicrobial Feed Additives, 1997; General Accounting Office, 1999; National Research council Institute of Medicine, 1998; van den Bogaard and Stobberingh, 1999; World Health Organization, 1997). These differences are due in large part to a dirth of quantitative data on the emergence, spread and selection of antibiotic resistance in the environment. Development of

\footnotetext{
* Corresponding author. Tel.: +41 44783 6416; fax: +41447836305. E-mail address: duffy@acw.admin.ch (B. Duffy).
}

quantitative methods to measure the influence of antibiotic use on the selection and spread of relevant antibiotic resistance determinants will facilitate acquisition of such critical data, and will thereby further efforts to design strategies that minimise potential for antibiotic resistance reservoir increase in exposed environments.

The most efficient method of detecting resistance in an environment with non-culturable bacteria is by specific detection of genes of interest from DNA extracted from the environmental sample. PCR is limited to determining if the gene is present or absent in the sample. In order to continuously monitor the effects of antibiotic use on the environmental bacteria and compare different sampling sites (e.g. soil with waste water treatment plants and water), the relative quantities of these resistance genes must be detected. Quantitative real-time PCR ( $\mathrm{qPCR}$ ) can be used to compare the levels of resistance genes present in an environment over time and in comparison to other environments. Thus, this technique offers a tool for delivering quantitative answers to questions concerning antibiotic effects on the development and spread of antibiotic resistance in the environment, and also concerning the potential role of environmental ecosystems as a reservoir for antibiotic resistance genes. The delta-delta $\mathrm{Ct}$ qPCR method compares relative changes or fluctuations in gene concentration (Livak and Schmittgen, 2001). This method was originally designed for the relative quantification of RNA in gene expression studies using housekeeping genes as endogenous controls. The relative quantification method has been adapted for the relative quantification of DNA and genes by utilising an endogenous control, which normalises the total quantity of bacterial DNA in the samples. Based on the $\mathrm{Ct}$ values this normalised data is compared to a positive 
Table 1

Strains and DNA used as positive controls.

\begin{tabular}{lll}
\hline Control strain & Genes & Source or reference \\
\hline Erwinia amylovora GRA-1A & strA, strB & G. McGhee, Michigan State Univ. \\
Plasmid pEA29 & IS1133 & \\
16S PCR products from soil bacteria & 16S & This study \\
& rRNA & \\
Escherichia coli NCTC 50269 plasmid & tet( $B)$ & Mendez et al. (1980) \\
Enterococcus faecalis plasmid & $\operatorname{tet}(M)$ & Riesen and Perreten (2009) \\
Escherichia coli plasmid & $\operatorname{tet}(W)$ & S. Karlsmose, Technical Univ. of \\
& & Denmark \\
Escherichia coli NCTC 13400 & aadA & Woodford et al. (2009) \\
$\quad$ plasmid pEK499 & & \\
\hline
\end{tabular}

control (Relative Quantity (RQ) value of 1 ). The RQ comparison results in a number, which indicates the quantity of the gene present relative to the quantity of positive control gene, which is set at 1 . The relative concentration of antibiotic resistance gene per sample can then be compared using a normalised data set. This facilitates comparison of different samples from different sample sites or different sample matrices.

We undertook a study to develop multiplex TaqMan ${ }^{\circledR}$ qPCR assays for the detection of the transferable streptomycin resistance genes strA (aph3), strB (aph6), aadA (ant3") and the insertion sequence associated with the str genes; IS1133 and the tetracycline resistance genes tetB, tetM and tet $W$. These genes were chosen as streptomycin is used in the prophylactic treatment of apple and pear orchards in certain European countries against fire blight and tetracycline is the second line of defense antibiotic against this bacterial disease and is frequently used in food-animal production (Emborg et al., 2007; Mayerhofer et al., 2009). In order to normalise the data the 16S rRNA gene was chosen. This gene has been previously used as the endogenous control gene in qPCR experiments (Hardwick et al., 2008;Zhang et al., 2000). As the genomes of all bacteria have not as yet been sequenced the exact number of copies of 16S rRNA genes per cell is currently unknown. Therefore, this may influence the quantities of genes detected. However, a compromise must be reached until the genomes of all non-culturable bacteria are sequenced.

\section{Materials and methods}

\subsection{DNA and bacteria}

Plasmid DNA containing the antibiotic resistance genes was extracted from the positive control isolates described in Table 1 using the Illustra ${ }^{\mathrm{TM}}$ Plasmid Prep Mini Spin Kit (GE Healthcare, Glattbrugg, Switzerland). Plasmid DNA was confirmed as positive for the respective genes by PCR amplification using the primers described for qPCR in Table 2. All PCR were performed with HotStar Taq polymerase (Qiagen AG, Basel, Switzerland) and an annealing temperature of $50{ }^{\circ} \mathrm{C}$.

\subsection{Microbial community samples and DNA extraction}

The biological samples were collected from apple orchards and the DNA was extracted within $48 \mathrm{~h}$ of sampling. The samples were stored at $4{ }^{\circ} \mathrm{C}$ during the $48 \mathrm{~h}$. Total soil DNA was extracted from eight pooled soil samples from the same orchard row using the MoBio ${ }^{\mathrm{TM}}$ Power Soil ${ }^{\circledR}$ DNA isolation kit (Süd-Laborbedarf GmbH, Gauting, Germany) according to the manufacturer instructions. Leaf, flower and apple fruit samples were washed in groups of eight samples per sample site in phosphate buffer solution and sonicated for $2 \mathrm{~min}$ in a sonicating water bath. DNA was extracted from the washes using the Qiagen DNeasy 96 Plant kit (Qiagen AG, Basel, Switzerland). The presence of DNA and absence of PCR inhibitors in all DNA extractions were confirmed by PCR of the 16S rRNA genes. The DNA concentrations were measured using a Nanodrop spectrophotometer (Fischer Scientific AG, Wohlen, Switzerland).

\subsection{Design and optimisation of $q P C R$}

Primers and TaqMan ${ }^{\circledR}$ probes used were adapted from prior studies or designed using Applied Biosystems Primer Express software (Applied Biosystems, Rotkreuz, Switzerland) (Table 2). All qPCR assays were performed on a 7500 Fast Real Time PCR system (Applied Biosystems, Rotkreuz, Switzerland). Each reaction contained 1× TaqMan ${ }^{\circledR}$ Environmental Mastermix 2.0 (Applied Biosystems, Rotkreuz, Switzerland), 450-1800 nM of each primer and 100$400 \mathrm{nM}$ of each probe initially to determine the optimum concentrations of primer and probe. Template DNA was added at final concentrations ranging from $10 \mathrm{fg}$ to $5 \mathrm{ng}$ for the optimisation and validation reactions. All qPCR were performed under the following conditions: $2 \mathrm{~min}$ at $50{ }^{\circ} \mathrm{C}, 10 \mathrm{~min}$ at $95^{\circ} \mathrm{C}$, and 40 cycles of $15 \mathrm{~s}$ at $95^{\circ} \mathrm{C}$ and $1 \mathrm{~min}$ at $60^{\circ} \mathrm{C}$. ROX was the internal reference dye. In order to determine the viability of the DNA extraction methods flower, leaf and soil samples were spiked with the positive control bacteria at concentrations in the range of $10^{7}-10^{9} \mathrm{CFU} / \mathrm{mL}$. The DNA was extracted and the qPCR performed as described for the samples. Aliquots of $5 \mathrm{ng}$ extracted DNA were used as DNA templates in the multiplex reactions.

\subsection{Optimisation process and determination of multiplex assay combinations}

The qPCRs were initially performed with varying concentrations of primers and probes from 100 to $1800 \mathrm{nM}$ for the primers and from 100 to $400 \mathrm{nM}$ for the probes in singleplex reactions with the DNA from the positive controls at concentrations from 1 to $5 \mathrm{ng}$. The primer and probe sets were tested at the optimum primer and probe concentrations using control DNA to develop the multiplex combinations as described in Table 3. The multiplex assays were evaluated with spiked sample DNA to ensure that they were not inhibited by the sample DNA or qPCR inhibitors. Spiked sample DNA consisted of a 50:50 mixture of positive control DNA with DNA extracted from

Table 2

Primers and probes used in the qPCR assays.

\begin{tabular}{|c|c|c|c|}
\hline Gene Target & Primer and probe sequences & $\begin{array}{l}\text { Amplicon 5' } \\
\text { to } 3^{\prime} \text { (bp) }\end{array}$ & Source or reference \\
\hline 16S rRNA & TCCTACGGGAGGCAGCAGT GGACTACCAGGGTATCTAATCCTGTT FAM-CGTATTACCGCGGCTGCTGGCAC-BHQ-1 & 466 & Nadkarni et al. (2002) \\
\hline IS1133 & GCAGCGTCGGGTTGGA ACGCGTTCGAACAACTGTAATG VIC-TTTGATGCGCCAGAATA-MGB & 58 & This study \\
\hline strA & TCAATCCCGACTTCTTACCG CACCATGGCAAACAACCATA JOE-TGCTCGACCAAGAGCGGC-BHQ-1 & 126 & This study \\
\hline \multirow[t]{2}{*}{$s t r B$} & ATCGCTTTGCAGCTTTGTTT ATGATGCAGATCGCCATGTA CY3-ATGCCTCGGAACTGCGT-BHQ-2 & 143 & This study \\
\hline & & 295 & van Overbeek et al. (2002) \\
\hline aadA & CAGCGCAATGACATTCTTGC GTCGGCAGCGACA(C/T)CCTTCG JOE-TGGTAGGTCCAGCGGCGGAG-BHQ-1 & & This study \\
\hline tetB & CGCGGCATCGGTCATT GAACCACTTCACGCGTTGAGA NED-CCGATACCACCTCAGC-MGB & 54 & This study \\
\hline tetM & GGTTTCTCTTGGATACTTAAATCAATCR CCAACCATAYAATCCTTGTTCRC JOE-ATGCAGTTATGGARGGGATACGCT ATGGY-BHQ-1 & 67 & Peak et al. (2007) \\
\hline tetW & CGGCAGCGCAAAGAGAAC CGGGTCAGTATCCGCAAGTT NED-CTGGACGCTCTTACG-MGB & 58 & This study \\
\hline
\end{tabular}


Table 3

Multiplex primer and probe combinations.

\begin{tabular}{ll}
\hline Triplex 1 & IS1133 \\
& tetW \\
& $16 \mathrm{~S}$ rRNA \\
Triplex 2 & tetB \\
& tetM \\
& $16 \mathrm{~S}$ rRNA \\
Triplex 3 & strA \\
& strB \\
Duplex & $16 \mathrm{~S}$ rRNA \\
& aadA \\
& $16 \mathrm{~S}$ rRNA \\
\hline
\end{tabular}

flower, leaf or soil to a final concentration of 1-5 ng. Each multiplex included an internal control 16S rRNA primer and probe set for relative quantification of the target genes in samples.

Relative quantification was performed using the delta-delta $\mathrm{Ct}$ method (Livak and Schmittgen, 2001). The relative quantity (RQ) of the genes was calculated using the comparative $\mathrm{Ct}$ program in the Applied Biosystems software. The relative quantity of antibiotic resistance gene present in the positive control samples was automatically set to one by the Applied Biosystems 7500 software. All of the samples were then compared to the quantity of antibiotic resistance gene in the positive control. When the antibiotic resistance gene was not detected in the sample no RQ value was calculated. The function of the endogenous control was to normalise the quantity of DNA in each of the samples (Hardwick et al., 2008), thus ensuring that the RQs of the target antibiotic resistance genes were not biased by differences in the quantity of bacteria or DNA present in the samples. Standard curve generation and delta-delta $\mathrm{Ct}$ values were calculated using Applied Biosystems software package. The percentage efficiency and the coefficient of determination $\left(R^{2}\right)$ of the reactions were determined from these serial dilutions. Efficiency $(E)$ was calculated using the equation: $E=10^{(-1 / \text { slope })} \times 100$ and automatically generated using the Applied Biosystems 7500 Real-Time PCR software package.

Detection limits, specificity and sensitivity for each singleplex and multiplex assay were determined. The qPCR singleplex and multiplex assays were validated by performing standard curve analysis on serial dilutions of positive control DNA at known concentrations and samples spiked with known concentrations of positive control DNA. The detection limit of each qPCR assay was determined from the serial dilutions of positive control DNA and spiked samples.

The four multiplexes were tested using DNA from soil samples. Eight soil samples were collected from farmland prior to and after fertilisation using pig manure and a soil sample from an apple orchard, which had never been exposed to pig manure. The DNA was extracted as described for the biological samples. Each sample was tested using the multiplexes described in Tables 2 and 3. The mastermix and DNA were pipetted in 96-well plates using an Eppendorf epMotion 5075 automatic pipetting system (VaudauxEppendorf AG, Basel, Switzerland). All reactions included 16S rRNA as an endogenous control and positive control DNA samples were used as reference samples.

\subsection{Specificity and sensitivity of the qPCR assays}

The assays utilised TaqMan ${ }^{\circledR}$ probes that were designed to bind specifically to the amplified region of each of the genes of interest. The cross-reactivity of primer and probe DNA sequences were checked using BLASTn to ensure that there was no potential cross reactivity with other genes or DNA sequences. The primer and probe sequences were chosen to ensure that they adhered to the guidelines described by Applied Biosystems [except for 16S rRNA gene as described by Nadkarni et al. (2002)].

\subsection{Determination of relative quantification values}

The $\mathrm{Ct}$ values for the $16 \mathrm{~S}$ and tet $\mathrm{B}$ genes from the positive control DNA were 18.5 and 16.7, respectively. The delta-delta $\mathrm{Ct}$ for the positive control was always 0 , as this is the positive control. The $\mathrm{RQ}\left(2^{\text {-deltadeltact }}\right)$ for the positive control $\left(2^{0}\right)$ was 1 . A sample had $\mathrm{Ct}$ values for the $16 S$ and tetB genes of 19.4 and 25.3 , respectively. The delta-delta Ct was 7.7. The RQ ( $\left.2^{\text {-deltadeltaCt }}\right)$ was 0.005 .

\section{Results}

\subsection{Determination and statistical analysis}

Samples were considered positive when qPCR Ct values for amplification exceeded thresholds prior to 35 cycles. False positives for the internal control 16S rRNA gene due to bacterial DNA contamination in the commercially supplied reagents had $\mathrm{Ct}$ values greater than 35 (Nadkarni et al., 2002).

\subsection{Primer and probe concentration optimisation}

Each primer and probe set concentration was optimised with the positive control DNA in a singleplex reaction. The optimum concentrations for all primers were $450 \mathrm{nM}$ with $100 \mathrm{nM}$ for the corresponding probe. The Ct values for $100 \mathrm{pg}$ of positive control DNA ranged from 19 to 29 for the antibiotic resistance genes (Table 4).

\subsection{Specificity, sensitivity and standard curves}

The presence of DNA and absence of PCR inhibitors in all DNA extractions were confirmed by PCR of the 16S rRNA genes. The results of these PCRs indicated that no PCR inhibitors we present. The sensitivity of the qPCR reactions were determined by the limit of detection of each assay (i.e., singleplexes, multiplexes and spiked samples with multiplexes). The limits of detection for the singleplexes ranged from $10 \mathrm{fg}$ to $1 \mathrm{pg}$ of positive control DNA as described in Table 4. In the multiplexes the limit of detection of the primers and probes was all within 10-fold DNA concentration of the singleplex limit of detection.

In order to study the matrix influence on the results, the $\mathrm{Ct}$ values of each assay containing positive control only DNA templates or spiked samples, at $100 \mathrm{pg}$ DNA concentrations were compared as described in Table 4. When the positive control reactions of singleplexes and multiplexes were compared the $\mathrm{Ct}$ values of the antibiotic resistance genes varied by less than $1.5 \mathrm{Ct}$, except for tetM which had an increase of $4 \mathrm{Ct}$ values from singleplex to multiplex. Therefore, the multiplex containing tetM required a longer cycling time than the singleplex or the other multiplexes. This may be due to the lower efficiency of the tetM primers and probe than the other primers and probes.

Standard curves were generated from the singleplex and multiplex assays by serial dilutions of the DNA templates. The percentage efficiency and the coefficient of determination $\left(R^{2}\right)$ of the reactions were determined from these serial dilutions (Table 4 ). The \% efficiency ranged from $87 \%$ to $109 \%$ for the singleplexes and $87-111 \%$ for the multiplexes. The \% efficiency of the $16 \mathrm{~S}$ primer and probe in the singleplex was $109 \%$, and in the multiplex $91-92 \%$.

\subsection{Validation of qPCR assays in environmental samples}

The limits of detection of the multiplexes when the spiked samples were used as the template DNA had no variation between sample types. They were also identical to the limits of detection of the multiplexes tested with positive control DNA only, except strB which had a 10-fold higher DNA concentration limit of detection of $10 \mathrm{pg}$. As the DNA extracted from the samples contained additional genomic 
Table 4

Validation results of singleplexes, multiplexes and multiplexes of environmental samples.

\begin{tabular}{|c|c|c|c|c|}
\hline \multirow[t]{2}{*}{ Gene singleplex } & \multirow[t]{2}{*}{ Ct $100 \mathrm{pg}^{\mathrm{a}}$} & \multirow[t]{2}{*}{ Ct threshold $^{\mathrm{b}}$} & \multirow{2}{*}{$\frac{\% \text { Efficiency }}{R^{2 \mathrm{~d}}}$} & \multirow[t]{2}{*}{ Limit of detection $^{\mathrm{e}}$} \\
\hline & & & & \\
\hline 16S rRNA & 8.12 & 0.026 & $\begin{array}{r}109 \\
0.9934\end{array}$ & $100 \mathrm{fg}$ \\
\hline IS1133 & 23.45 & 0.081 & $\begin{array}{l}98 \\
0.9991\end{array}$ & $10 \mathrm{fg}$ \\
\hline strA & 23.38 & 0.007 & $\begin{array}{l}98 \\
0.9889\end{array}$ & $10 \mathrm{fg}$ \\
\hline$s t r B$ & 21.63 & 0.008 & $\begin{array}{r}95 \\
1\end{array}$ & $10 \mathrm{fg}$ \\
\hline $\operatorname{aad} A$ & 25.48 & 0.066 & $\begin{array}{l}97 \\
0.9949\end{array}$ & $100 \mathrm{fg}$ \\
\hline tetB & 19.46 & 0.042 & $\begin{array}{l}99 \\
0.9998\end{array}$ & $10 \mathrm{fg}$ \\
\hline tetM & 29.57 & 0.102 & $\begin{array}{l}89 \\
0.9964\end{array}$ & $1 \mathrm{pg}$ \\
\hline tetW & 19.92 & 0.035 & $\begin{array}{r}101 \\
0.9928\end{array}$ & $10 \mathrm{fg}$ \\
\hline \multirow[t]{2}{*}{ Gene multiplex } & Ct $100 \mathrm{pg}$ & Ct threshold & \% Efficiency & Limit of detection \\
\hline & & & $\overline{R^{2}}$ & \\
\hline 16S rRNA & 15.09 & 0.021 & $\begin{array}{l}92 \\
0.9966\end{array}$ & $10 \mathrm{fg}$ \\
\hline IS1133 & 24.51 & 0.102 & $\begin{array}{l}92 \\
0.9989\end{array}$ & $100 \mathrm{fg}$ \\
\hline tetW & 20.84 & 0.033 & $\begin{array}{r}111 \\
0.9956\end{array}$ & $10 \mathrm{fg}$ \\
\hline 16S rRNA & 19.95 & 0.027 & $\begin{array}{l}91 \\
0.98\end{array}$ & $100 \mathrm{fg}$ \\
\hline strA & 24.83 & 0.007 & $\begin{array}{l}95 \\
0.9414\end{array}$ & $100 \mathrm{fg}$ \\
\hline$s t r B$ & 22.98 & 0.012 & $\begin{array}{l}98 \\
0.9931\end{array}$ & $10 \mathrm{fg}$ \\
\hline 16S rRNA & 15.47 & 0.021 & $\begin{array}{l}92 \\
0.998\end{array}$ & $10 \mathrm{fg}$ \\
\hline tetB & 20.96 & 0.039 & $\begin{array}{r}103 \\
0.9941\end{array}$ & $10 \mathrm{fg}$ \\
\hline tetM & 34.14 & 0.084 & $\begin{array}{r}87 \\
1\end{array}$ & $10 \mathrm{pg}$ \\
\hline 16S rRNA & 19.93 & 0.079 & $\begin{array}{l}91 \\
0.9943\end{array}$ & $10 \mathrm{fg}$ \\
\hline $\operatorname{aad} A$ & 26.57 & 0.066 & $\begin{array}{l}96 \\
0.9991\end{array}$ & $100 \mathrm{fg}$ \\
\hline
\end{tabular}

\begin{tabular}{|c|c|c|c|c|c|c|c|}
\hline \multirow{2}{*}{$\begin{array}{l}\text { Gene } \\
\text { multiplex }\end{array}$} & \multicolumn{3}{|c|}{ Ct $100 \mathrm{pg}$} & \multirow{2}{*}{$\begin{array}{l}\mathrm{Ct} \\
\text { Threshold }\end{array}$} & \multicolumn{3}{|c|}{ Limit of detection } \\
\hline & Flower & Leaf & Soil & & Flower & Leaf & Soil \\
\hline IS1133 & 26.25 & 26.38 & 26.22 & 0.0848 & $100 \mathrm{fg}$ & $100 \mathrm{fg}$ & $100 \mathrm{fg}$ \\
\hline tetW & 22.32 & 22.45 & 22.43 & 0.030 & $10 \mathrm{fg}$ & $10 \mathrm{fg}$ & $10 \mathrm{fg}$ \\
\hline strA & 29.93 & 30.94 & 27.54 & 0.005 & $100 \mathrm{fg}$ & $100 \mathrm{fg}$ & $100 \mathrm{fg}$ \\
\hline$s t r B$ & 23.50 & 23.44 & 23.71 & 0.013 & $100 \mathrm{fg}$ & $100 \mathrm{fg}$ & $100 \mathrm{fg}$ \\
\hline tetB & 22.03 & 22.05 & 22.03 & 0.0406 & $10 \mathrm{fg}$ & $10 \mathrm{fg}$ & $10 \mathrm{fg}$ \\
\hline tetM & 31.61 & 31.60 & 31.59 & 0.0361 & $10 \mathrm{pg}$ & $10 \mathrm{pg}$ & $10 \mathrm{pg}$ \\
\hline $\operatorname{aad} A$ & 25.64 & 25.61 & 26.12 & 0.021 & $100 \mathrm{fg}$ & $100 \mathrm{fg}$ & $100 \mathrm{fg}$ \\
\hline
\end{tabular}

a Cycle at which the amplification of the gene of interest crossed the threshold at a DNA template concentration of $100 \mathrm{pg}$.

b The level of detection or the point at which a reaction reaches a fluorescent intensity above background.

c $\mathrm{E}=10^{(-1 / \text { slope })} \times 100$

d Coefficient of variation.

e The lowest concentration of DNA detectable by qPCR.

DNA the limits of detection of 16S rRNA primers and probe could not be reliably determined in these samples.

In the spiked samples the tetM Ct value in the multiplex assay was within $2 \mathrm{Ct}$ values of the singleplex $\mathrm{Ct}$ value. There was very little variation in the $\mathrm{Ct}$ values of the multiplexes between the spiked flower, soil and leaf samples, when compared for the same gene. The
Table 5

Detection of antibiotic resistance genes in bacteria spiked environmental samples .

\begin{tabular}{llll}
\hline Gene & Ct spiked flower & Ct spiked leaf & Ct spiked soil \\
\hline IS1133 & 23.07 & 27.70 & 20.85 \\
tetW & 23.89 & 18.55 & 21.53 \\
strA & 25.85 & 30.86 & 24.26 \\
strB & 23.80 & 28.21 & 21.91 \\
tetB & 23.42 & 26.00 & 20.42 \\
tetM & 24.91 & 28.16 & 26.12 \\
aadA & 25.80 & 22.60 & 17.51 \\
\hline a $\mathrm{Ct}=$ Threshold cycle. & &
\end{tabular}

Ct values in comparison to the positive control DNA template multiplexes were within 2-3 Ct values.

Apple flower, apple leaf and soil samples were spiked with $10^{7}-10^{9} \mathrm{CFU} / \mathrm{mL}$ of the positive control bacteria. Aliquots of $5 \mathrm{ng}$ of extracted DNA were used as DNA template in the multiplexes. The strA, strB, IS1133, aadA, tetB, tetM and tetW genes were all detected in the DNA extracted from the bacteria spiked samples. The $\mathrm{Ct}$ values for the samples are described in Table 5. The standard curves of the singleplex and multiplex reactions using the positive control DNA or the spiked samples were similar.

The relative quantification of each gene in the DNA extracted from farmland soils are described in Table 6. The quantity of DNA per sample was automatically normalised using the 16S rRNA gene to remove anomalies caused by variations in the DNA concentrations of the different soils. The function of the endogenous control was to normalise the quantity of DNA in each of the samples, thus ensuring that the RQs of the target antibiotic resistance genes were not biased by the difference in the quantity of bacteria or DNA present in the samples. The $16 \mathrm{~S}$ rRNA gene was detected in all samples.

The genes that were identified most frequently in the soil samples prior to fertilisation were $s t r B, a a d A$, tetB and tetM. All eight sample sites contained higher levels of tetM than the positive control (Table 6). Both tetB and strB were present in seven out of eight sampled sites. The genes that were only present in one or two sample sites were IS1133, strA and tetW. Therefore, all genes were detected in at least one soil sample. In the same soil sample sites after fertilisation

Table 6

Relative quantification (RQ) of resistance genes in pasture soil before and after manure fertilisation and orchard soil without manure fertilisation.

\begin{tabular}{|c|c|c|c|c|c|c|c|}
\hline \multirow[t]{2}{*}{ Gene } & IS1133 & strA & strB & $\operatorname{aad} A$ & tetB & tetM & tetW \\
\hline & RQ & RQ & RQ & RQ & RQ & $\mathrm{RQ}$ & RQ \\
\hline \multicolumn{8}{|c|}{ Pasture soil prior to fertilisation } \\
\hline \multicolumn{8}{|c|}{ March 2010} \\
\hline A & 0.08 & 10.00 & 0.30 & 28.00 & 0.03 & 18.04 & 3.58 \\
\hline B & $\mathrm{ND}^{\mathrm{a}}$ & ND & 0.0004 & ND & ND & 2.06 & ND \\
\hline $\mathrm{C}$ & ND & ND & 0.01 & 2.03 & 0.002 & 22.80 & 3.10 \\
\hline $\mathrm{D}$ & ND & ND & 0.003 & 0.19 & 0.005 & 6.46 & ND \\
\hline $\mathrm{E}$ & ND & ND & 0.01 & 0.75 & 0.05 & 60.00 & ND \\
\hline $\mathrm{F}$ & ND & ND & 0.002 & 0.15 & 0.001 & 2.15 & ND \\
\hline G & ND & ND & ND & ND & 0.35 & 110.56 & ND \\
\hline $\mathrm{H}$ & ND & ND & 0.003 & ND & 0.001 & 3.78 & ND \\
\hline
\end{tabular}

Pasture soil after fertilisation September 2010

$\begin{array}{llllllrl}\text { A } & \text { ND } & \text { ND } & 0.0002 & \text { ND } & 0.0003 & 0.43 & 0.41 \\ \text { B } & \text { ND } & \text { ND } & 0.002 & \text { ND } & \text { ND } & 4.33 & 1.39 \\ \text { C } & \text { ND } & \text { ND } & 0.01 & 0.02 & \text { ND } & 6.48 & 6.50 \\ \text { D } & \text { ND } & \text { ND } & 0.006 & 0.13 & \text { ND } & 12.80 & 1.55 \\ \text { E } & \text { ND } & \text { ND } & 0.03 & 0.46 & 0.06 & 125.40 & \text { ND } \\ \text { F } & \text { ND } & \text { ND } & \text { ND } & \text { ND } & \text { ND } & 0.38 & \text { ND } \\ \text { G } & \text { N.17 } & \text { ND } & \text { ND } & \text { ND } & \text { ND } & 88.30 & \text { ND } \\ \text { H } & \text { ND } & \text { ND } & \text { ND } & \text { ND } & 0.00007 & 0.08 & \text { ND }\end{array}$

Orchard soil

$\begin{array}{lllll}0.0001 & 0.0005 & 0.01 & \text { ND } & \text { ND }\end{array}$ $0.21 \quad 0.017$

${ }^{a}$ ND indicates resistance gene was not detected. 
with pig manure there was an overall decrease in the number of resistance genes detected. However, tetM and strB were the most frequently identified resistance genes and tet $M$ also contained high RQ levels in five sample sites. The presence of tet $W$ was maintained in two sample sites and was detected in two additional sample sites after fertilisation. In the orchard soil IS1133, strA, strB, tetM and tetW were detected. All were present at low levels in comparison to the other two soils.

\section{Discussion}

Streptomycin and oxytetracycline are the primary first and second line control treatments for fire blight, caused by the enterobacterial phytopathogen Erwinia amylovora, during the bloom period of apple and pear (McManus et al., 2002). The tetracycline class of antibiotics are also frequently used for growth promotion in the cattle and swine industry (U.S. Department of Agriculture, 1996, 2000). While phenotypic testing of resistance to these antibiotics is possible it is restricted only to the detection of resistance in culturable bacteria. PCR detection can merely detect the presence of antibiotic resistance genes, whereas qPCR can quantify the fluctuations in the presence of antibiotic resistance genes over time or in the comparison of different sample sites.

Most previous studies investigating antibiotic resistance mechanisms in the environment have focused on the PCR detection of resistance genes (Binh et al., 2008, 2009; Heuer and Smalla, 2007; Nikolakopoulou et al., 2005; van Overbeek et al., 2002). Singleplex qPCR using SYBR green detection has previously been used to detect certain antibiotic resistance genes in environmental samples, most frequently identified in water or waste water samples (Volkmann et al., 2004, 2007; Borjesson et al., 2009; Knapp et al., 2008; Koike et al., 2007; Pruden et al., 2006; Smith et al., 2004). The SYBR Green RT-PCR chemistry may generate false positive results as it binds to any double-stranded DNA, and as such can also bind to non-specific double-stranded DNA sequences. The TaqMan ${ }^{\circledR}$ probe based RT-PCR requires specific hybridization between probe and target to generate a fluorescent signal and therefore does not generate false positives by non-specific binding. In order to make TaqMan ${ }^{\circledR}$ qPCR cost effective it is imperative to maximise the number of genes that can be quantified with the least amount of reagents and thus the lowest costs. The Taqman ${ }^{\circledR}$ multiplex qPCR developed in this study provides the simultaneous detection and relative quantification of antibiotic resistance genes, thereby reducing the costs associated with Taqman ${ }^{\circledR}$ assays, and enables the relative quantification of antibiotic resistance genes in complex matrices. This is a great improvement over the current techniques of PCR or Sybr Green RT-PCR as it is extremely specific to the target gene and may be used to quantify the presence of antibiotic resistance genes in DNA extracted from different sample sites and types. This is of importance when studying the continuous effects of antibiotics or other selective factors on the emergence or increase in the presence of antibiotic resistance genes in nature.

This study describes the development and validation of highly sensitive and specific multiplex qPCR assays for the relative quantification of streptomycin and tetracycline resistance in flower, leaf and soil samples. The results illustrated the reproducibility of the assays in environmental samples and the reproducibility between DNA extractions from the different environmental matrices of flower, leaf and soil. These multiplex qPCR assays enable the simultaneous detection and relative quantification of multiple resistance genes from the environment. Previous studies have quantified the presence of antibiotic resistance genes using qPCR but only in singleplex assays. Our assays can be used to analyse the increasing or decreasing quantities of streptomycin and tetracycline resistance genes in the environment. Thus, we will be able to reliably determine whether the use of these antibiotics in agriculture increases abundance of these genes in the environment. The development process of these assays can also be used as a template for the development of other qPCR tools for the detection of other antibiotic resistance genes in environmental samples. Due to the presence of the 16S rRNA gene endogenous control it is possible to compare quantification results from different sample sites and different sample matrices. The assays were performed in 96-well format and therefore could easily be automated using robotics. This facilitates rapid quantification of resistance genes in large numbers of samples simultaneously. The qPCR assays developed in this study can be implemented for the comparison of the levels of these resistance genes in the environment and provide a template and guideline of how to develop further qPCR assays for the relative quantification of antibiotic resistance genes in the environment.

The detection of all resistance genes in at least one soil sample demonstrates that the multiplex qPCR reactions are capable of quantifying all resistance genes in environmental samples. There was an overall reduction in the quantities of streptomycin resistance genes and tetB detected in the soils after the application of manure. However, the quantities of tetM and tet $W$ were maintained or increased. Both tet $M$ and tet $W$ mediate resistance by ribosomal protection, whereas tet $B$ confers resistance by efflux. The alterations in antibiotic resistance gene concentrations could be due to the addition of bacteria or additional resistance genes contained in the manure, which out-compete the natural soil bacteria when manure is added. Most studies on the detection of tetracycline resistance genes have focused on wastewater treatment plants, water or manure (Borjesson et al., 2009; Hölzel et al., 2010; Wu et al., 2010). These studies have detected the presence of tetracycline resistance genes, rather than identifying the influence of anthropologic effects on the increase or decrease of tetracycline resistance genes. There have been few studies investigating the presence of streptomycin resistance genes in soil samples treated with manure (Binh et al., 2009). This study indicated that streptomycin resistance gene aadA was introduced by fertilisation with manure. The results of our study disagree with these findings and show the importance of both quantifying the genes present and comparing the soil before and after manure was added.

\section{Acknowledgements}

This project was funded by the Swiss Federal Office for Agriculture and the Swiss Federal Office for the Environment. The work was conducted within the European research networks COST 864 and COST TD0803. The authors thank Prof. Dr. J. Frey (Univ. of Bern, Bern, Switzerland) and Dr. V.O. Stockwell (Oregon State Univ., Corvallis, OR, USA) for helpful discussion and Dr. G. McGhee (Michigan State Univ., East Lansing, MI, USA), Prof. Dr. V. Perreten (Univ. of Bern) and Dr. S. Karlsmose (Technical Univ. of Denmark) for providing reference strains.

\section{References}

Binh, C.T.T., Heuer, H., Kaupenjohann, M., Smalla, K., 2008. Piggery manure used for soil fertilization is a reservoir for transferable antibiotic resistance plasmids. FEMS Microbiol. Ecol. 66, 25-37.

Binh, C.T.T., Heuer, H., Kaupenjohann, M., Smalla, K., 2009. Diverse aadA gene cassettes on class 1 integrons introduced into soil via spread manure. Res. Microbiol. 160 427-433.

Borjesson, S., Dienues, O., Jarnheimer, P.A., Olsen, B., Matussek, A., Lindgren, P.E., 2009 Quantification of genes encoding resistance to aminoglycosides, beta-lactams and tetracyclines in wastewater environments by real-time PCR. Intl. J. Environ. Health Res. 19, 219-230.

Commission on Antimicrobial Feed Additives, 1997. Antimicrobial Feed Additives. Ministry of Agriculture, Stockholm, Sweden.

Emborg, H.D., Vigre, H., Jensen, V.F., Vieira, A.R., Baggesen, D.L., Aarestrup, F.M. 2007. Tetracycline consumption and occurrence of tetracycline resistance in Salmonella typhimurium phage types from Danish pigs. Microbiol. Drug Resist. 13, 289-294.

General Accounting Office, 1999. Food Safety: The Agricultural Use of Antibiotics and Its Implications for Human Health. General Accounting Office, Washington, D.C., USA 
Goldman, E., 2004. Antibiotic abuse in animal agriculture: exacerbating drug resistance in human pathogens. Human Ecol. Risk Assess. 10, 121-134.

Gould, I.M., 1999. A review of the role of antibiotic policies in the control of antibiotic resistance. J. Antimicrob. Chemother. 43, 459-465.

Hardwick, S.A., Stokes, H.W., Findlay, S., Taylor, M., Gillings, M.R., 2008. Quantification of class 1 integron abundance in natural environments using real-time quantitative PCR. FEMS Microbiol. Lett. 278, 207-212.

Heuer, H., Smalla, K., 2007. Manure and sulfadiazine synergistically increased bacteria antibiotic resistance in soil over at least two months. Environ. Microbiol. 9, 657-666.

Hölzel, C.S., Harms, K.S., Küchenhoff, H., Kunz, A., Müller, C., Meyer, K., et al., 2010. Phenotypic and genotypic bacterial antimicrobial resistance in liquid pig manure is variously associated with contents of tetracyclines and sulfonamides. J. Appl. Microbiol. 108, 1642-1656.

Knapp, C.W., Engemann, C.A., Hanson, M.L., Keen, P.L., Hall, K.J., Graham, D.W., 2008 Indirect evidence of transposon-mediated selection of antibiotic resistance genes in aquatic systems at low-level oxytetracycline exposures. Environ. Sci. Technol. 42, 5348-5353.

Koike, S., Krapac, I.G., Oliver, H.D., Yannarell, A.C., Chee-Sanford, J.C., Aminov, R.I., et al., 2007. Monitoring and source tracking of tetracycline resistance genes in lagoons and groundwater adjacent to swine production facilities over a 3-year period. Appl. Environ. Microbiol. 73, 4813-4823.

Livak, K.J., Schmittgen, T.D., 2001. Analysis of relative gene expression data using realtime quantitative PCR and the 2( - delta delta C(T)) method. Methods 25, 402-408.

Mayerhofer, G., Schwaiger-Nemirova, I., Kuhn, T., Girsch, L., Allerberger, F., 2009. Detecting streptomycin in apples and orchards treated for fire blight. J. Antimicrob. Chemother. 63, 1076-1077.

McManus, P.S., Stockwell, V.O., Sundin, G.W., Jones, A.L., 2002. Antibiotic use in plant agriculture. Annu. Rev. Phytopathol. 40, 443-465.

Mendez, B., Tachibana, C., Levy, S.B., 1980. Heterogeneity of tetracycline resistance determinants. Plasmid 3, 99-108.

Nadkarni, M.A., Martin, F.E., Jacques, N.A., Hunter, N., 2002. Determination of bacteria load by real-time PCR using a broad-range (universal) probe and primers set. Microbiology 148, 257-266.

National Research Council Institute of Medicine, 1998. The use of drugs in food animals: benefits and risks. Committee on Drug Use in Food Animals report. National Academy Press, Washington, D.C., USA.

Nikolakopoulou, T., Egan, S., van Overbeek, L., Guillaume, G., Heuer, H., Wellington, E.M.H., et al., 2005. PCR detection of oxytetracycline resistance genes $\operatorname{otr}(\mathrm{A})$ and $\operatorname{otr}(\mathrm{B})$ in tetracycline-resistant streptomycete isolates from diverse habitats. Curr. Microbiol. 51, 211-216.

Peak, N., Knapp, C.W., Yang, R.K., Hanfelt, M.M., Smith, M.S., Aga, D.S., et al., 2007. Abundance of six tetracycline resistance genes in wastewater lagoons at cattle feedlots with different antibiotic use strategies. Environ. Microbiol. 9, 143-151.

Pruden, A., Pei, R.T., Storteboom, H., Carlson, K.H., 2006. Antibiotic resistance genes as emerging contaminants: studies in northern Colorado. Environ. Sci. Technol. 40, $7445-7450$.
Rezzonico, F., Stockwell, V.O., Duffy, B., 2009. Plant agricultural streptomycin formulations do not carry antibiotic resistance genes. Antimicrob. Agents Chemother. 53, 3173-3177.

Riesen, A. And, Perreten, V., 2009. Antibiotic resistance and genetic diversity in Staphylococcus aureus from slaughter pigs in Switzerland. Schweiz Arch. Tierheilkd. 151, 425-431.

Smith, M.S., Yang, R.K., Knapp, C.W., Niu, Y.F., Peak, N., Hanfelt, M.M., et al., 2004. Quantification of tetracycline resistance genes in feedlot lagoons by real-time PCR. Appl. Environ. Microbiol. 70, 7372-7377.

U.S. Department of Agriculture, 1996. Swine ‘95. II. Reference of 1995 U.S. Grower/ Finisher Health and Management Practices. USDA APHIS VS CEAH. National Animal Health Monitoring System, Fort Collins, CO, USA.

U.S. Department of Agriculture, 2000. III. Health Management and Biosecurity in U.S. Feedlots 1999. No. N336.1200.USDA APHIS VS CEAH. National Animal Health Monitoring System, Fort Collins, CO, USA.

van den Bogaard, A., Stobberingh, E., 1999. Antibiotic usage in animals: impact on bacterial resistance and public health. Drugs 58, 589-607.

van den Bogaard, A., Stobberingh, E.E., 2000. Epidemiology of resistance to antibiotics: links between animals and humans. Int. J. Antimicrob. Agents 14, 327-335.

van Overbeek, L.S., Wellington, E.M.H., Egan, S., Smalla, K., Heuer, H., Collard, J.M., et al., 2002. Prevalence of streptomycin-resistance genes in bacterial populations in European habitats. FEMS Micobiol. Ecol. 42, 277-288.

Volkmann, H., Schwartz, T., Bischoff, P., Kirchen, S., Obst, U., 2004. Detection of clinically relevant antibiotic-resistance genes in municipal wastewater using real-time PCR (TaqMan®). J. Microbiol. Meth. 56, 277-286.

Volkmann, H., Schwartz, T., Kirchen, S., Stofer, C., Obst, U., 2007. Evaluation of inhibition and cross-reaction effects on real-time PCR applied to the total DNA of wastewater samples for the quantification of bacterial antibiotic resistance genes and taxonspecific targets. Mol. Cell. Probes 21, 125-133.

Wegener, H.C., 2003. Antibiotics in animal feed and their role in resistance development. Curr. Opin. Microbiol. 6, 439-445.

Witte, W., 1998. Medical consequences of antibiotic use in agriculture. Science 279, 996-997.

Woodford, N., Carattoli, A., Karisik, E., Underwood, A., Ellington, M.J., Livermore, D.M., 2009. Complete nucleotide sequences of plasmids pEK204, pEK499 and pEK516, encoding CTX-M enzymes in three major Escherichia coli lineages from the United Kingdom, all belonging to the international 025:H4-ST131 clone. Antimicrob. Agents Chemother. 53, 4472-4482.

World Health Organization, 1997. The Medical Impact of the Use of Antimicrobials in Food Animals. World Health Organization, Geneva, Switzerland.

Wu, N., Qiao, M., Zhang, B., Cheng, W.D., Zhu, Y.G., 2010. Abundance and diversity of tetracycline resistance genes in soils adjacent to representative swine feedlots in China. Environ. Sci. Technol. 44, 6933-6939.

Zhang, L., Fan, F., Palmer, L.M., Lonetto, M.A., Petit, C., Voelker, L.L., et al., 2000. Regulated gene expression in Staphylococcus aureus for identifying conditional lethal phenotypes and antibiotic mode of action. Gene 255, 297-305. 